\title{
A Study of the Persuasive Arts in a Modest Proposal
}

\author{
Guo Lei, Wang Lan \\ English Department, North China Electric Power University, Baoding, China
}

Email address:

g1_guolei@qq.com (Guo Lei), 1428986974@qq.com (Wang Lan)

\section{To cite this article:}

Guo Lei, Wang Lan. A Study of the Persuasive Arts in a Modest Proposal. Humanities and Social Sciences. Vol. 4, No. 2, 2016 , pp. 60-65. doi: $10.11648 /$ j.hss.20160402.17

Received: February 28, 2016; Accepted: April 28, 2016; Published: May 5, 2016

\begin{abstract}
A Modest Proposal is a representative work of Jonathan Swift. Many critics think it a greatest satirical work ever written. Jonathan Swift has always been considered a political writer and poet. His plain style can also been seen in $A$ Modest Proposal but it's not the main concern of this thesis. This thesis mainly focuses on some artistic features of the famous pamphlet. One characteristic of this essay is about the discussion of the persuasive devices used by Jonathan Swift. And some rhetorical devices and themes are also discussed in this thesis. In the end, the general idea of this thesis is concluded.
\end{abstract}

Keywords: A Modest Proposal, Persuasive Devices, Rhetorical Devices

\section{Introduction}

Jonathan Swift, churchman, political writer and poet, is the foremost satirist in the English language and one of the satiric masters of all time. He was born in Dublin, Ireland on 30 November 1667. Seven months before Jonathan was born, his father was died. His mother returned to England and he was left in the care of his influential uncle, Godwin. His uncle arranged his education, and he sent him with one of his cousins to Kilkenny College. In 1682, Swift attended Dublin University (Trinity College, Dublin), from where he received his BA in 1686. After Jonathan graduated from Trinity College, he went to England to try his luck. He found a job as secretary to Sir William Temple, a retired statesman who was busy with tending his gardens and writing essays. Jonathan wrote a lot of stuff in between tutoring sessions, but only few of them survived. But when Sir William died in 1699, Jonathan was left scrambling for a job and eventually ended up with several odd little Church positions back in Ireland. He became a very fashionable satiric writer as far as Dublin society was concerned.

A Modest Proposal for Preventing the Children of Poor People in Ireland from being a burden to Their Parents or Country, and for Making Them Beneficial to the Public has been regarded by many as the most savage single piece of ironical satire ever written.

Jonathan bitterly criticizes the British government in this essay by suggesting that the children be fatten and eaten. $\mathrm{He}$ gave his own advice from the point of a projector. Readers are shocked and frightened by his suggestion that the children of the poor be served as delicacy of the rich in Ireland under the age of one. Even a vicious tiger will not eat its cubs - no man, good or bad, will ill-treat his own children. Jonathan shows great concern over the poverty issues and the ineptitude of the government of England. He enumerated a list of benefits of this practice in the proposal in all seriousness.

A lot of people criticize this essay from the author's writing style. Some concentrates on Jonathan Swift's plain style, some focuses on the satire effects of the essay, this thesis offers a new perspective on this essay by analyzing the persuasive devices and rhetorical devices the author used.

Ireland went through several years of famine in the $1720 \mathrm{~s}$, where harvest failures forced many of the poor to use up their stock of potatoes sooner than usual, leaving several months in the year of famine unprovided for $[2,7]$. At times, grain had to be imported rather than exported, and prices rose to the point where they were higher in Dublin than in London [4]. Mobs in the south of Ireland were stopping the shipment of their grain sold to help those in need in the north, there was rioting at ports where corn was being exported, and unemployed weavers were feeding on grain and sheep's blood from slaughterhouses [4, 9]. The impact of this shortage of food was suggested by M. B. Draper in "A Letter to the People of Ireland" (1729), where he wrote that, "If they [the Irish] happen to hear of the Death of a Horse, they run to it as to a Feast". 
The British government then enacted some policies severely restricted Ireland's trade. Heavy tariffs were placed on cattle and sheep imported from Ireland by the English according to the Cattle Acts in 1633 [3]. Not only trade in meat products were banned, but also woolen goods. England then passed a law prohibiting Ireland from exporting its woolen goods to any country, and a few ports in England were only open to 'unworked' wool exported from Ireland. For these reasons, a large number of farmers and weavers were forced to beg for their bread.

Writing and speaking are two basic tasks for non-native speakers. Generally, people communicate with others or give opinions by an article or a speech. Argumentative writing is a very useful writing category for it concludes many different writing skills. Argumentation needs its writer put forward his/her view on something and try to persuade his/her readers. Some necessary skills like rhetoric are very useful when people want to persuade others by writing an essay or giving a speech. A Modest Proposal is a persuasive essay where Swift utilized the most powerful skill to "persuade" people to "accept" his advice.

Jonathan Swift wants to persuade people to "accept" the proposal proposed by the Projector. A Modest Proposal is famous for its writing style and the ironical effects. Students are always puzzled by some English writing skills and do not clearly know how to use these skills. How to organize an article and how to persuade readers are two difficult points in writing. By analyzing the persuasive devices and rhetorical devices in A Modest Proposal, readers can get a general glimpse of writing good argumentation and Jonathan Swift's thoughts.

This thesis focuses on how the author uses the three persuasive appeals: ethos, logos and pathos, how the author uses rhetorical devices in this essay and through the analysis how the author persuades his readers to "accept" the Projectors proposal.

In order to study further the persuasive skills the author used in this essay and try to give readers a careful picture of persuasive usage, some careful studies have been conducted in this thesis. The purpose of this thesis is to explain the usage of some persuasive appeals and rhetorical devices in $A$ Modest Proposal, and give readers a general understanding of the author's thoughts on then Ireland's social issues.

This section will provide a brief description on the significance of the study given the analysis on the essay from the persuasive appeals and rhetorical devices. This thesis will give people a general understanding of the art of persuasion, the usage of some rhetorical devices, some themes of the essay indirectly expressed by the author and the great effects of the use of satire.

This thesis is divided into five parts. The first part is the introduction, where the research background, research motivation and research questions, research purpose and research significance and the outline of this essay are explained. Chapter Two presents the literature review. Chapter Three focuses on three persuasive appeals used in A Modest Proposal. Chapter Four looks for some rhetorical devices used in the essay. The conclusion part generally gives the main discoveries of the essay.

This thesis is mainly based on the original work of Jonathan Swift's A Modest Proposal (1729). This thesis studies the persuasive and rhetorical art of this essay, and at the same time it also briefly introduces Jonathan Swift the person and then social background.

The group of works which have introduced the great satirist Jonathan Swift and the background mainly includes: Feast and Famine: A History of Food in Ireland by K. A. Clarkson and E. Margaret Crawford, which includes a general introduction to the poverty issue in Ireland; Jonathan Swift on the Lives of the Poor Native Irish as Seen Through "A Modest Proposal" and Other of His Writings by Patrick Welch, which focuses on "A Modest Proposal" and other of his writings that were prompted by the unsustainable socio-economic and geo-political conditions under which the poor native Irish were living; Irish Agricultural Production: Its Volume and Structure by Raymond D. Crotty tells the agricultural condition of then Ireland. These works have given a general description of the author and the background.

The works which mainly studies the persuasive appeals is Rhetoric by Aristotle which focuses on the use of language as both a vehicle and a tool to shape persuasive argument. This thesis cites some definitions or thoughts from the Chinese version of Rhetoric.

The groups of works which have studied rhetorical art include: A Hand Book of English Rhetorical Devices by Feng Cuihua and $A$ Handbook of Rhetorical Devices by Robert A. Harris, which have introduced a list of English rhetorical devices commonly used in English writing. The usage of some rhetorical devices is explained in these two books. The author has successfully used some classical rhetorical devices in $A$ Modest Proposal.

\section{Devices of Persuasion}

\subsection{Ethos}

Ethos, or argument by character, employs the persuader's personality, reputation, and ability to look trustworthy. From the etymology, Ethos originates from a Greek word ethikos, which means moral or showing moral character. What Aristotle think is that a speaker must establish his moral credibility from the very beginning and then the audience will give credit to what the speaker said.

The Projector wants to persuade his audience to accept his suggestion that children of one year old be fatten and eaten which he thinks is the best way to solve the poverty issue and relieve the overpopulation problem in then Ireland.

It is a melancholy Object to those, who walk through this great Town, or travel in the Country, when they see the Streets, the Roads, and Cabin-Doors, crowded with Beggars of the female Sex, followed by three, four, or six Children, all in Rags, and importuning every Passenger for an Alms. These Mothers instead of being able to work for their honest livelihood, are forced to employ all their time in Strolling, to 
beg Sustenance for their helpless Infants, who, as they grow up either turn Thieves for want of work, or leave their dear native Country to fight for the Pretender in Spain, or sell themselves to the Barbadoes. [11]

At the very beginning, the Projector describes the sympathetic scene in Ireland and tells the reader that there are many poor parents who are supposed to be engaged in a job to support their families are begging in the streets. Readers are very likely to have sympathy for these parents and their children. Through the description of the circumstances of then Ireland, Swift successfully attracted the readers' attention and also the landlords' and the Politicians'. At this point, the Projector has established his primary credit among his readers. However, the Projector is brave enough to put forward his "reasonable" but actually appalling suggestion.

Although the projector makes readers ready to listen to his following words carefully, he does give his readers a scare and arouse their interests and curiosity. People who have read through the first part of the essay think the author may show his concern on the poverty issue forwardly or give some feasible advice on this problem. Surprisingly, the author did not follow the regular practice, and only the readers who have read his suggestion do realize how ironic his suggestion is.

\subsection{Logos}

Logos is argument by logic. The word Logos originates from Greek and it stands by logic and orderliness. "Is that an argument or statement appealing to the audience's capacity for reason, logic or sensibility? Can you trust the speaker's use of logic?" are two questions readers should always bear in their minds to check the logic of a writer or a speaker.

At first, the Projector presents a miserable image: women and children are begging on the streets of Ireland. These mothers, unable to work for their livelihood, "are forced to employ all their Time" panhandling for food. The children, also for want of work, grow up to be thieves, or else emigrate "to fight for the Pretender" or to seek their fortunes in the Americas. [10]

He then begins to detail his proposal. The Projector carefully calculates the amount of children and the profits these children could bring to their parents and the country. He even suggests that the thrifty landlords flay the Carcass. He also mentions the refinement of his scheme by "a true lover of his country": replace the want of venison with "the Bodies of young Lads and Maidens, not exceeding fourteen Years of Age".

Furthermore, the proposer thinks that he has "too long digressed", and therefore he returns to his subject. He continues to enumerate the advantages of his proposal: poor tenants, national economy, marriage, mothers' love for their children, exportation of beef and a standard of other meats will all get more or less profits from the practice of his proposal. Thus, readers may reach a consensus that his proposal is undoubtedly "a fair, cheap and easy method of making these Children sound and useful Members of the common-wealth".
Finally, for fear of an objection to his proposal, he first admits that the practice may reduce the population of the country, and then he points out that other alternative solutions are naïve and unrealistic for these solutions neglect two urgent issues: how 100,000 "useless Mouths and Backs" are to be fed and clothed and how to address the extreme poverty of the vast majority of the Irish population. [10] The proposer "having been wearied out for many Years with offering vain, idle, visionary thoughts and at length utterly despairing of Success", he "fortunately fell upon this Proposal". The proposer emphasizes that he has only the public Good of his country in his mind and has not the least personal interest in this proposal. What a "loyal and duteous" statesman he is!

From the order of this essay, the persona the author presents is a statesman who is weary of the inadequate solutions of the concerning issues of this country and puts forward a practical method to solve those problems. Readers are inclined to side with the proposer at the very beginning for the proposer does not give his reason. It becomes very clearly that this is an irony and at the same time a "hypocritical" persuasive essay when cannibalism which is the least possible accepted by almost all normal and emotional people appears next in this essay.

From the ironic effect of this essay, the logic of the Projector is reasonable and well organized: the Projector first depicts the miserable scene in Ireland, then he presents his worries, next he solemnly puts forward his proposal, and then he enumerates the advantages of his proposal and points that the revise of his scheme and other alternative solutions are unrealistic, at last he is just for the good of the public instead for any personal interests.

\subsection{Pathos}

Pathos is argument by emotion. Pathos is also a Greek-originated word, and its first meaning is "to suffer or to endure". The body is suffering or enduring when people have some feelings like anger, sympathy, fears and so on. Whether an argument can appeal to or strike a chord with its reader or audience depends on whether it can evoke emotional response from its reader or audience. Swift uses many "proper words in proper place" to evoke readers emotional responses however sympathetic or indignant they are.

Initially, the author pictures that those parents who are not "able to work for their honest livelihood" are "forced to employ all their time" begging on the streets in Ireland and sometimes they are followed by their children who are very likely to "turn Thieves for want of work, or leave their dear native Country to fight for the Pretender in Spain, or sell themselves to the Barbadoes".

This melancholy scene evokes the soft and tender feeling of sympathy in readers' heart. The successful use of Pathos in the first part of this essay easily makes readers feel that the author take sides with the poor masses, while the author only places that miserable circumstance from an objective and indifferent point of view.

The author's attitude of neutrality could conclude from the 
following part of this tract: one of the advantages the author enumerated in the tract is that it will prevent "those voluntary Abortions". However, from the author's point of view the reason why those women murder their "poor innocent Babes" is not shame but the financial expense of themselves. This is a ridiculous practice: mothers kill their babies for want of money. Many great mothers bring up their children no matter how tough the circumstances are and they will never abandon their children just because of money. The Projector thinks money far outweighs maternal love which deviates from normal moral standards.

This Pathos in the first part is actually used with irony, and the details will be explained in the next part of this thesis.

The Projector suggests that the more thrifty gentlemen of quality can "flay the Carcass". Thus the skin of these infants could be made into "admirable Gloves for Ladies and Summer Boots for fine Gentlemen". Following this the Projector even recommends that buy "the Children alive" and dress them hot "from the Knife" just like roasting pigs. These persons of quality, fine gentlemen and ladies are all representatives of upper classes. These landlords or the rich regardless of the serious social issues in Ireland take no action to solve these problems but just care about their own profits. People first feel scared, disgusted, then angry, and finally indignant. No one could have a safe and sound sleep in the night if this proposal is put into practice. The author uses Pathos in this part evokes emotional responses in readers. The more indignant the readers feel, the more ironic people think this proposal is.

\section{Rhetorical Devices}

\subsection{Irony}

Irony is a figure of speech that achieves emphasis by saying the opposite of what is meant, the intended meaning of the words being the opposite of their usual sense. This irony is called verbal irony [5]. There are mainly three types of irony: verbal irony, dramatic irony and situational irony. Dramatic irony applies mainly to drama, and has to do with the plot and structure of a play. In this type of irony, the audience is aware of something which is a character on the stage is still ignorant of. Situational irony is a relatively modern use and it describes a sharp discrepancy between the expected result and actual results in a certain situation. In this famous pamphlet, Swift mainly employs the powerful verbal irony.

I think it is agreed by all Parties, that this prodigious number of Children, in the Arms, or on the Backs, or at the heels of their Mothers, and frequently of their Fathers, is in the present deplorable state of the Kingdom a very great additional grievance; and therefore whoever could find out a fair, cheap and easy method of making these Children sound and useful Members of the common-wealth would deserve so well of the public, as to have his Statue set up for a preserver of the Nation. [11]

At this point, readers think this is a statesman in a pensive mood who is concerned with his country and his people. It appears to the Projector that the children of a prodigious number are not the hope of the country, but a very great additional grievance. The author tells all this in a soothing and serious tone. It seems to readers that the Projector is a social activist who spends a lot of efforts for the survival of the nation. It's naturally that hope springs eternal from readers. They hope the Projector could think up a good and instant way to help people out of misery.

I shall now therefore humbly propose my own thoughts, which I hope will not be liable to the least Objection. [11]

I have been assured by a very knowing American of my acquaintance in London, that a young healthy Child well Nursed is at a year Old, a most delicious, nourishing, and wholesome Food, whether Stewed, Roasted, Baked, or Boiled, and I make no doubt that it will equally serve in a Fricassee, or Ragout. [11]

Unexpectedly, what the Projector gives is to sell the children under one year old to the tables of the rich except those who are reserved for breed. In order to prove the proposal is reasonable, the author proposes courteously and acts in all apparent seriousness to quote accurate estimate statistic figures. The Projector hopes his proposal will not meet with any least objection, while anyone with a conscience will surely oppose this practice. People will only be shocked by the "delicious, nourishing and wholesome" food served on the table.

A Child will make two Dishes at an Entertainment for Friends, and when the Family dines alone, the fore or hind Quarter will make a reasonable Dish, and seasoned with a little Pepper or Salt will be very good Boiled on the fourth Day, especially in Winter. [11]

If "A child" is placed with any other animals, people will naturally think it is a recipe, but they haven't expected the ingredient should be a child. Surprisingly, any tiny bit of compassion could not be read between the lines and it's hard to find any human emotion mingled within the text. The calm attitude of the author and his blood-boiling proposal of cannibalism form a sharp contrast, thus the effects of irony are achieved by the disharmony between the form and the content of language.

I grant this food will be somewhat dear and therefore very proper for Landlords, who, as they have already devoured most of the Parents, seem to have the best Title to the Children. [11]

The author assumes that his audience, regardless of their national or religious affiliations or their socioeconomic status, will all agree to the fact that eating children is morally reprehensible. It is impossible for the audience to accept the "dear" food to be served on tables. The Landlords who have been consuming these poor parents now should turn their greedy hands to those poor children. The Landlords are the least likely to have the right to squeeze the poor tenants, while the Projector thinks they have "the best title" to devour their children. Immediately, people recognize clearly the greedy essence of the landlords from this use of irony. 


\subsection{Metaphor}

A metaphor is a figure of speech that describes a subject by asserting that it is, on some point of comparison, the same as another otherwise unrelated object. Metaphor compares two different things by speaking of one in terms of the other. Unlike a simile or analogy, metaphor asserts that one thing is another thing, not just that one is like another.

Swift continuously uses graphic and gripping metaphor throughout this essay to parallel the Irish peasants to animals. There are mainly three kinds of metaphor in this essay: the Irish peasants to animals, children to animals and children to currency or goods.

I grant this food will be somewhat dear, and therefore very proper for Landlords, who, as they have already devoured most of the Parents, seem to have the best Title to the Children. [11]

The landlord have "devoured" the parents in the sense of excessive taxation and collecting high rent. Humans eat while beasts devour. It's clearly that the Parents and their children are compared to the meal of "beasts" and at the same time the Irish Landlords are compared to cruel beasts. The Irish peasants and children are treated like animals by their landlords and the English. The author is comparing physically eating to financially destroying by using "devour". What he is trying to elaborate on is the landlords' financially destroying their tenants (this would be the tenor of the metaphor). He uses devour (the vehicle of the metaphor) to explain that financial destruction. Another "proper" word used in "proper" place in this paragraph is "the best Title". "Devour" gives readers a stunning shock, while the author next shift to use a refined phrase "the best Title". The contrast between "devour" and "the best Title" is clear-cut: the "devour" becomes more graceless.

It is true a Child, just dropt from its Dam. [11]

I have been assured by a very knowing American of my acquaintance in London, that a young healthy Child well Nursed is at a year Old, a most delicious, nourishing, and wholesome Food, whether Stewed, Roasted, Baked, or Boiled, and I make no doubt that it will equally serve in a Fricassee, or Ragout. [11]

A Child will make two Dishes at an Entertainment for Friends, and when the Family dines alone, the fore or hind Quarter will make a reasonable Dish, and seasoned with a little Pepper or Salt will be very good Boiled on the fourth Day, especially in Winter. [11] the Skin of which, Artificially dressed [11].

"Dropt from its Dam" are words used only for an animal being born. The author also metaphorically compares children to a piece of animal flesh which will become a delicious cuisine on the plates of the rich, for there are various ways to cook "a young healthy Child": stewing, roasting, baking or boiling. Besides, the author describes a picture that animals are butchered on the chopping boards, cooked into dishes on the dinner tables and even their skin is manufactured into gloves and boots.

Men would become as fond of their Wives, during the Time of their Pregnancy, as they are now of their Mares in Foal, their Cows in Calf, or Sows when they are ready to Farrow, nor offer to Beat or Kick them (as is too frequent a practice) for fear of a Miscarriage. [11]

The parents are paralleled to animals and dehumanized by being referred to as "breeders" several times in the essay.

Secondly, the poorer Tenants will have something valuable of their own, which by Law may be made liable to Distress, and help to pay their Landlord's Rent, their Corn and Cattle being already seized, and Money a thing unknown. [11]

For this kind of Commodity will not bear Exportation, the Flesh being of too tender a Consistence, to admit a long continuance in Salt... [11]

Lastly the author compares children to currency which could be used to pay rent and to goods which could not be exported for their flesh is too tender to be reserved.

By using metaphors, the treatment of the Irish peasants as less than human by the English is depicted.

\subsection{Understatement}

An understatement is a figure of speech employed by writers or speakers to intentionally make a situation seem less important than it really is. An understatement usually has an ironic effect as an equally intense response is expected in severe situations but the statement in response is opposite.

Understatement deliberately expresses an idea as less important than it actually is, either for ironic emphasis or for politeness and tact. When the writer's audience can be expected to know the true nature of a fact which might be rather difficult to describe adequately in a brief space, the writer may choose to understate the fact as a means of employing the reader's own powers of description [1]. In order to achieve the effect of belittlement, the author adopts the strategy of understatement in his essay. Actually, understatement is a form of irony, while it has its own feature: it decreases the degree of seriousness in some circumstances.

The greatest example of understatement in this essay is the title-- A Modest Proposal, for after the reader has read a few paragraphs of the pamphlet, he knows that Swift's proposal is anything but modest--it is outrageous.

Those who are more thrifty (as I must confess the Times require) may flay the Carcass; the Skin of which, Artificially dressed, will make admirable Gloves for Ladies, and Summer Boots for fine Gentlemen. [11]

The skin of children is not "suitable" for any sensible man to make a pair of gloves or boots, not to mention "admirable" gloves. The author uses understatement here to achieve an ironic effect. His intention is to assail the cruel treatment of the English and the Irish landlords towards Irish peasants.

...some scrupulous People might be apt to Censure such a Practice, (although indeed very unjustly) as a little bordering upon Cruelty... [11]

Some people might think the practice of using the body of maidens to take place of venison is just "a little" bordering upon cruelty. This inhuman and horrific practice only shocks and enrages people.

There are also many other skillful uses of understatement 
in this pamphlet. The author intends to understate abnormal and immoral things and in the fact readers get stronger indignation from his plain words.

\section{Conclusion}

The purpose of this thesis is to study some persuasive appeals and rhetorical devices used in Jonathan Swift's $A$ Modest Proposal. The thesis approaches its goal from following aspects: the persuasive ways of the essay and the rhetorical devices used in the essay. In every part, the definition, the character and the usage of persuasive and rhetorical arts are explained in this essay. Jonathan Swift is a writer of fluency and felicity. He once said "Proper words in proper places make the true definition of style". In this thesis, the study of specific use of words is not the main task, while some rhetorical analyses give some examples of his "proper" style. Through the study of persuasive and rhetorical art of the essay, this thesis presents the logic of the author, the layout of the essay and some themes of the essay. Through this thesis, students can get a better understanding of persuasive appeals and the usage of some rhetorical devices, and they can also express their ideas or thoughts effectively and accurately.

\section{Acknowledgments}

First of all, I would like to express my sincere thanks to all those who helped me during the writing of this thesis. I gratefully acknowledge the help of my supervisor, professor Guo, who has offered me valuable suggestions in the preparation of this thesis. He has spent much time reading through each draft and provided me with inspiring advice. Without his patient introduction, insightful criticism and expert guidance, the completion of this thesis would not have been possible.

Second, special thanks should go to my friends and classmates who have put considerate time and energy in helping me work out my problems during the difficult course of the thesis.

Last, I should like to express my gratitude to my beloved family for their loving considerations and great confidence in me all these years.

\section{References}

[1] A. Harris, Robert, A Handbook of Rhetorical Devices, Version Date: October 11, 2008.

[2] Clarkson, K. A. and Margaret Crawford, E. Feast and Famine: A History of Food in Ireland, 1500-1920. Oxford: Oxford University Press. 2001.

[3] D. Crotty, Raymond. Irish Agricultural Production: Its Volume and Structure, Cork: Cork University Press. 1966.

[4] Ehrenpreis, Irvin. Swift: The Man, His Works, and the Age, MA: Harvard University Press. 1983.

[5] Feng Cuihua. A Hand Book of English Rhetorical Devices. Beijing: Foreign Language Teaching and Research Press, 2005.

[6] M. Metchick, Nicole. Defoe's Realism and Swift's Satire, Southern Connecticut University. 1999.

[7] N. Salaman, Redcliffe. The History and Social Influence of the Potato, Cambridge: Cambridge University Press. 1986.

[8] Reed, Joel. Academically Speaking Language and Nationalism in Seventeenth- and Eighteenth Century, University of California, Irvine. 1991.

[9] Scott, Temple. The Prose Works of Jonathan Swift, D.D, London: George Bell and Sons. 1905.

[10] Spark Notes Editors. "Spark Note on A Modest Proposal." SparkNotes.com. Spark Notes LLC. n.d. Web. 30 Apr. 2014.

[11] Swift, Jonathan. "A Modest Proposal", History and Anthology of English literature [M]. Beijing: Foreign Language Teaching and Research Press, 2005: 212-223.

[12] Wallace Byron C. Computation irony: A survey and new perspectives, Artificial Intelligence Review [J]. New York: Springer Netherlands. 2015, pp 467-483.

[13] Welch, Patrick. Jonathan Swift on the Lives of the Poor Native Irish as Seen Through "A Modest Proposal" and Other of His Writings, Journal of the History of Economic Thought, 35, 2013, pp 471-489. 